\title{
CORRECTION OF SEVERE DYSTROPHIC SCOLIOSIS IN NEUROFIBROMATOSIS 1 WITH POSTERIOR VERTEBRAL COLUMN RESECTION IN MULTIPLE LEVELS
}

\author{
CORREÇÃO DA ESCOLIOSE DISTRÓFICA GRAVE NA NEUROFIBROMATOSE 1 POR \\ VERTEBRECTOMIA POSTERIOR MÚLTIPLOS NIVEIS
}

\section{CORRECCIÓN DE ESCOLIOSIS DISTRÓFICA GRAVE EN NEUROFIBROMATOSIS 1 CON VERTEBRECTOMÍA POSTERIOR EN MÚLTIPLES NIVELES}

\begin{abstract}
Alderico Girão Campos de Barros, ${ }^{1}$ luís Eduardo Carell Teixeira da Silva, ${ }^{1}$ Júlo Alves Ponte, ${ }^{1}$ Gustavo Borges laurindo Azevedo, Renato João Muniz Teixeira, ${ }^{1}$ Andre Luiz Loyelo Barcellos ${ }^{1}$
\end{abstract}

1. Instituto Nacional de Traumatologia e Ortopedia, Rio de Janeiro, RJ, Brazil.

\begin{abstract}
Objective: To evaluate the results after multiple posterior vertebral column resection (PVCR) in patients with severe kyphoscoliosis secondary to neurofibromatosis type 1 (NF-1). Methods: Retrospective study of 4 adult male patients, mean age of 26.5 years, with severe rigid deformity, mean kyphosis of $122^{\circ}$ and scoliosis of $88^{\circ}$, through clinical analysis and complementary exams. Results: The mean postoperative follow-up was 27 months. Three vertebrae were resected on average. Interbody consolidation of arthrodesis was confirmed by CT in all cases. The correction rates of sagittal and coronal deformities were $54.09 \%$ and $70.45 \%$, respectively. Prior to surgery, all patients were neurologically intact and as a post-surgical complication one patient had motor deficit (ASIA D) and pneumothorax also occurred in two patients. Conclusions: The correction of severe kyphoscoliosis in adult patients with NF-1 is technically demanding and is not free of major complications. However, in view of the limited possibility of correction of these deformities, multiple-level PVCR has proved to be a safe and effective technique. Level of evidence IV; Case Series.
\end{abstract}

Keywords: Neurofibromatoses; Kyphosis; Osteotomy.

\section{RESUMO}

Objetivo: Avaliar os resultados após a ressecção vertebral posterior (RCVP) múltiplos níveis em pacientes portadores de cifoescoliose grave secundária à neufibromatose tipo 1 (NF-1). Métodos: Estudo retrospectivo de 4 pacientes: adultos do sexo masculino, idade média de 26,5 anos, portadores de deformidade rígida e grave, cifose média de $122^{\circ}$ e escoliose média de $88^{\circ}$, por meio da análise clínica e exames complementares. Resultados: O seguimento pós-operatório médio foi de 27 meses. Foram ressecadas, em média, três vértebras. Consolidação intersomática da artrodese foi confirmada por TC em todos os casos. As taxas de correção das deformidades sagital e coronal foram de $54,09 \%$ e 70,45\%\%, respectivamente. Previamente à cirurgia, todos os pacientes eram neurologicamente intactos e, como complicação, um paciente apresentou déficit motor (ASIA D). Ocorreu ainda pneumotórax em dois pacientes. Conclusão: A correção da cifoescoliose grave em pacientes adultos portadores NF-1 é tecnicamente exigente e não está isenta de complicações maiores. Porém, diante da possibilidade restrita de técnicas de correção dessas deformidades, a RCVP múltiplos níveis mostrou-se uma técnica segura e eficaz. Nível de evidência IV; Série de Casos

Descritores: Neurofibromatose; Cifose; Osteotomia.

\section{RESUMEN}

Objetivo: Evaluar los resultados después de la resección vertebral posterior (RPCV) en múltiples niveles en pacientes con cifoescoliosis grave secundaria a neurofibromatosis tipo 1 (NF-1). Métodos: Estudio retrospectivo de 4 pacientes adultos del sexo masculino, con promedio de edad de 26,5 años, con deformidad rígida grave, cifosis promedio de $122^{\circ}$ y escoliosis promedio de $88^{\circ}$, mediante un análisis clínico y exámenes complementarios. Resultados: El seguimiento postoperatorio promedio fue de 27 meses. Tres vértebras fueron resecadas en promedio. La consolidación de la artrodesis intersomática fue confirmada por la TC en todos los casos. Los porcentajes de corrección de las deformidades coronales y sagitales fueron de 54,09\% y 70,45\%, respectivamente. Antes de la cirugía, todos los pacientes estaban intactos neurológicamente y un paciente tuvo déficit motor como complicación (ASIA D) y dos pacientes tuvieron neumotórax. Conclusiones: La corrección de la cifoescoliosis graves en pacientes adultos con NF-1 es técnicamente exigente y no está exenta de complicaciones mayores. Sin embargo, en vista de la posibilidad limitada de corrección de estas deformidades, la RPCV de múltiples niveles ha demostrado ser una técnica segura y eficaz. Nivel de evidencia IV; Serie de Casos.

Descriptores: Neurofibromatosis; Cifosis; Osteotomía. 


\section{INTRODUCTION}

Neurofibromatoses (NF) are a group of hereditary, multisystem, hamartomatous alterations involving products from all germinative lineages: ectoderm, mesoderm, and endoderm. This disease can be divided into peripheral or type 1 (NF-1) and central or type 2 (NF-2) neurofibromatoses. The most common form is NF-1 or Von Recklinghausen disease. NF-2 affects the central nervous system and is associated with multiple spinal schwannomas. ${ }^{1,2}$

There are also two presentation subtypes: segmental neurofibromatosis, with the characteristics of NF-1 and present in a single corporal segment, and schwannomatosis, a mosaic form of NF-2. $\mathrm{NF}-1$ is the only form associated with spinal deformities. ${ }^{3}$

Described for the first time in 1918 by Gould, spinal deformities associated with NF-1 were identified as the principal orthopedic manifestations of this condition. ${ }^{4}$ Kyphoscoliosis is defined as scoliosis accompanied by kyphosis greater than 50 degrees, being the major cause of deficit in NF-1 and in many cases associated with severe deformity. ${ }^{5}$ There are two curve patterns in spinal deformity: dystrophic and non-dystrophic. The non-dystrophic deformities of $\mathrm{NF}-1$ are the most common and can be treated similarly to idiopathic curves. On the other hand, the deformities associated with dystrophic alterations are rare but malignant in nature, presenting as short-radius curves, associated angular kyphosis, and radiographic alterations that include vertebral wedging, dural ectasia, meningocele, enlargement of the intervertebral foramen, and excavation of the vertebral body. ${ }^{6}$

The therapeutic possibilities for correction of severe and rigid curves in NF-1 are quite limited and technically demanding, which is why we often find "neglected" patients with severe kyphoscoliosis. Associated with these factors is the additional difficulty of access by these patients to specialized spinal surgery centers. The existing global literature about this scenario is scarce and to our knowledge there are few studies about the surgical management of severe kyphoscoliosis in NF-1 using posterior vertebral column resection (PVCR) ${ }^{6,7}$ This technique has the advantage of high power or correction, especially in angular and rigid deformities, because it promotes circumferential decompression and mobilization of the three column spine of Denis. .,9 $^{8}$
The objective of our study is to evaluate the results obtained from and the feasibility of the PVCR technique for the treatment of severe rigid kyphoscoliosis in adult patients with NF-1

\section{METHODS}

We conducted a retrospective study through clinical and radiological evaluation of correction using the multiple-level PVCR technique for the treatment of severe kyphoscoliosis in patients with NF-1 with a history of onset before 10 years of age. Four adult male patients with a mean age of 26.5 years $(23-32)$ at the time of surgery, and who met the criteria for clinical diagnosis of NF-1 proposed in 1988, were evaluated..$^{10}$ All the patients had dystrophictype deformities and were neurologically intact, ASIA E, and were operated by the same surgical team.

Surgical planning was conducted with a neurological examination, panoramic radiographs of the spine, and computed tomography with axial, coronal, and sagittal reconstructions. The kyphosis and scoliosis angular values, pedicular dysplasia, the presence of luxation of the costovertebral joint, excavation of the vertebral bodies, an increase in diameter of the intervertebral foramina, and laminar defects were assessed. All the curves were short-radius and the mean preoperative magnitude of the kyphosis was $122^{\circ}$ $\left(100^{\circ}-171^{\circ}\right)$ and of the associated scoliosis was $88^{\circ}\left(72^{\circ}-109^{\circ}\right)$, measured using SURGIMAP ${ }^{\circledR}$ software. (Figure 1)

PVCR Surgical Technique: All surgeries were performed in the presence of two surgeons from the same team, with the patient under intraoperative neuromonitoring. With the patient in the prone position, exposure of the spine and instrumentation with pedicle screws were performed. A temporary rod modeled in situ is connected to the screws unilaterally to stabilize the spine during the process of resection of the vertebral elements. Following costectomy of approximately $6 \mathrm{~cm}$ of each costal arch of the vertebral body to be resected, subperiosteal dissection through the lateral vertebral wall is performed. During this procedure it is important to control bleeding from lesions of segmental arteries. Under direct visualization, resection of the periapical vertebral bodies and discs adjacent to the PVCR are performed in accordance with the clinical analysis and supported by intraoperative fluoroscopy, always from lateral to

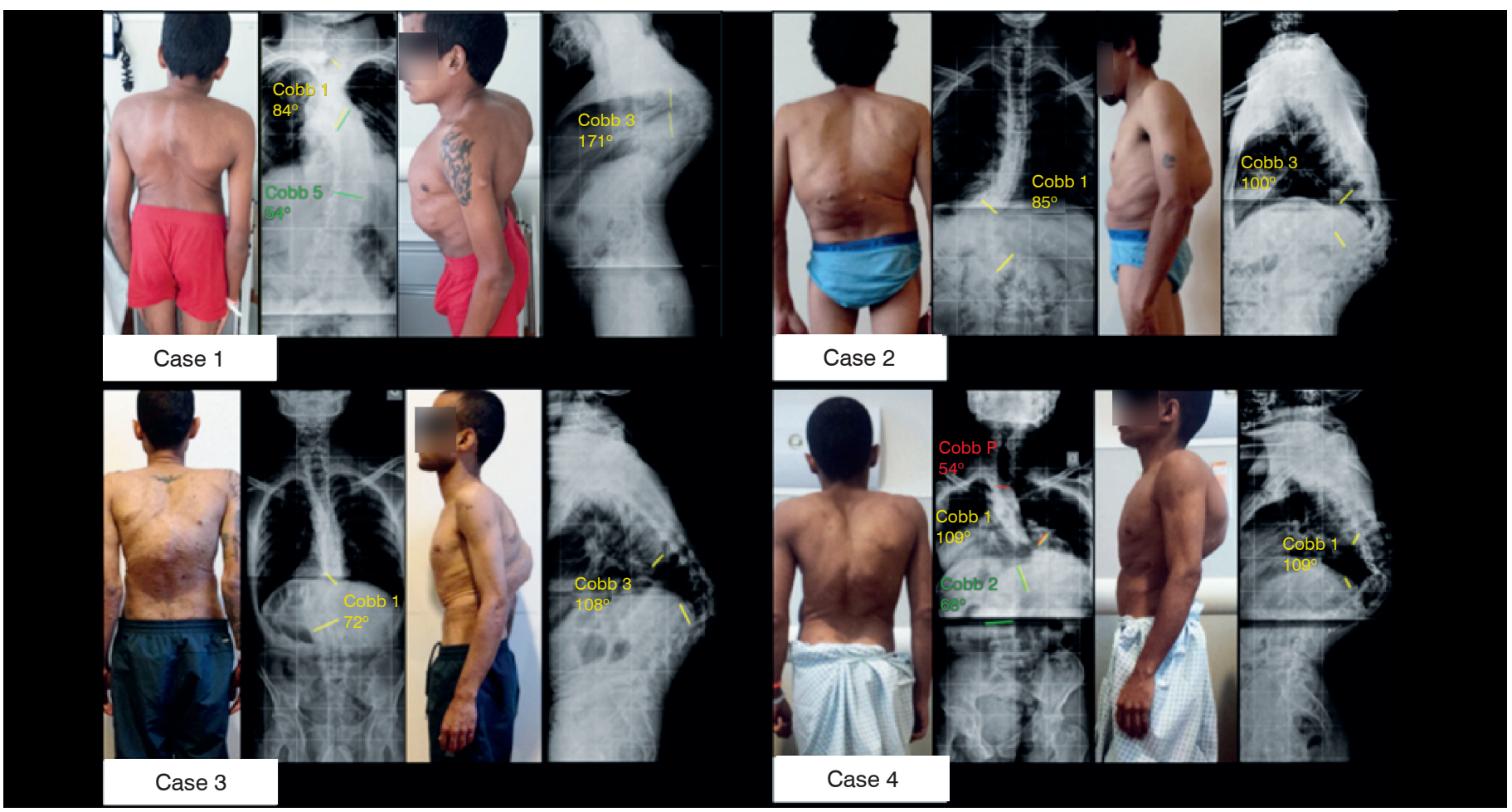

Figure 1. Preoperative clinical presentation and radiographical images of the four study patients. 
medial, leaving the posterior vertebral wall, which protects the dura mater, to be resected in the final stage following epidural hemostasis. With the anterior and posterior release, the temporary rod is replaced by another premolded rod and various deformity correction maneuvers are performed, such as, compression/distraction, cantilever, and in situ modeling. A titanium mesh cage containing autologous graft from the ribs and anterior and posterior elements is positioned between the remaining terminal plates. Multiple complete facetary osteotomies are performed for additional flexibility, using the technique described by Ponte. ${ }^{11}$ Posterior vertebral decortication with grafting and closure of the wound by planes are performed. When there is pleurotomy, a thoracic drain is installed once the patient is in the supine position.

\section{RESULTS}

The mean residual deformity in degrees after correction in the coronal plane was $26^{\circ}$, with a rate of correction of $70.45 \%$. The mean residual deformity in degrees after correction in the sagittal plane was $56^{\circ}$, with a rate of correction of $54.09 \%$. (Figure 2) On average, $3(2-5)$ vertebral bodies were resected. The assessment of bone consolidation, evaluated using CT six months following surgery, showed fusion of the arthrodesis in 100\% of cases, confirmed by the presence of a bone bridge inside the cage. (Figure 3) There were no instrumentation material failures in any of the study cases. All patients used a TLSO brace for a minimum period of six months. (Figure 4)

In this study of four patients with middle term follow-up, two patients had intraoperative neurological deficit, one of whom remained with ASIA D in the lower limbs after 6 months. Other complications were the presence of postoperative pneumothorax in two patients, which we attributed to the distorted anatomy and difficulty identifying the anatomic plane. Both presented benign evolution, and the chest drains were removed prior to the 7 th postoperative day.

\section{DISCUSSION}

Spinal deformities are identified as the main orthopedic manifestation associated with NF-1, present in from 2 to $16 \%$ of cases. ${ }^{4}$
Deformities characterized as dystrophic behave aggressively, with important vertebral excavation and, therefore, require a combination of anterior and posterior stabilization, ${ }^{12}$ particularly in young patients. ${ }^{13}$ Even deformities that do not present as dystrophic initially may change their radiological and clinical patterns, a phenomenon known as modulation. ${ }^{14}$ In a study by Sirois et al., 23 (72\%) out of the 32 patients evaluated with vertebral deformity had dystrophic curves. The incidence of pseudoarthrosis was 38\% for the dystrophic group submitted to isolated posterior fusion. The rate of correction loss was $12.7 \%$ and an average of 1.7 procedures was required for stable posterior fusion and they concluded that kyphoscoliotic curves should be treated with combined anterior and posterior fusion. ${ }^{15}$ In their study, Durrani et al. observed that $81 \%$ of the young patients with NF-1 and non-dystrophic curves suffered the phenomenon of modulation, developed manifestation of dystrophic kyphoscoliosis. ${ }^{4}$

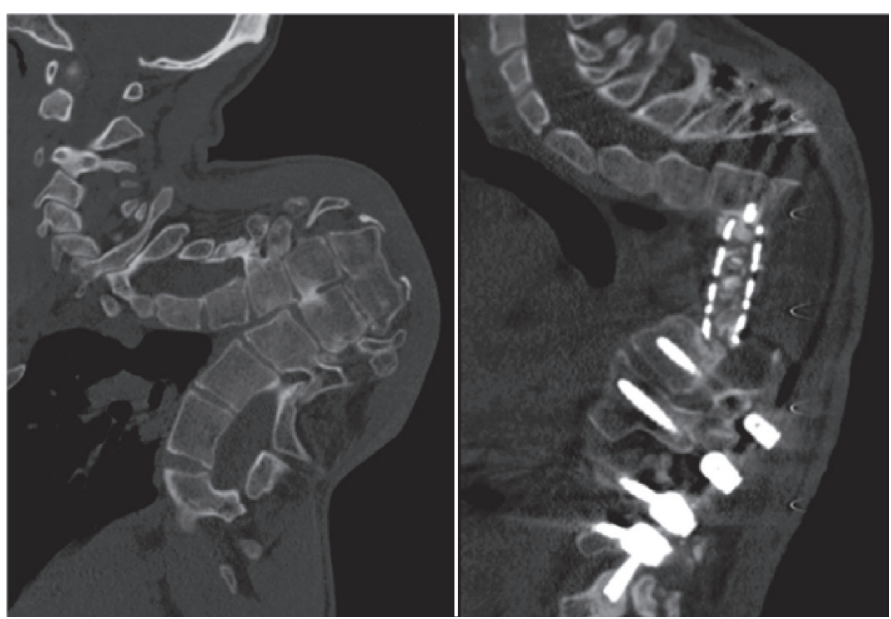

Figure 3. Sagittal reconstruction of the computed tomography examination, in the preoperative period and six months following surgery, showing resection of the five vertebral bodies and consolidation of the arthrodesis inside the titanium cage.

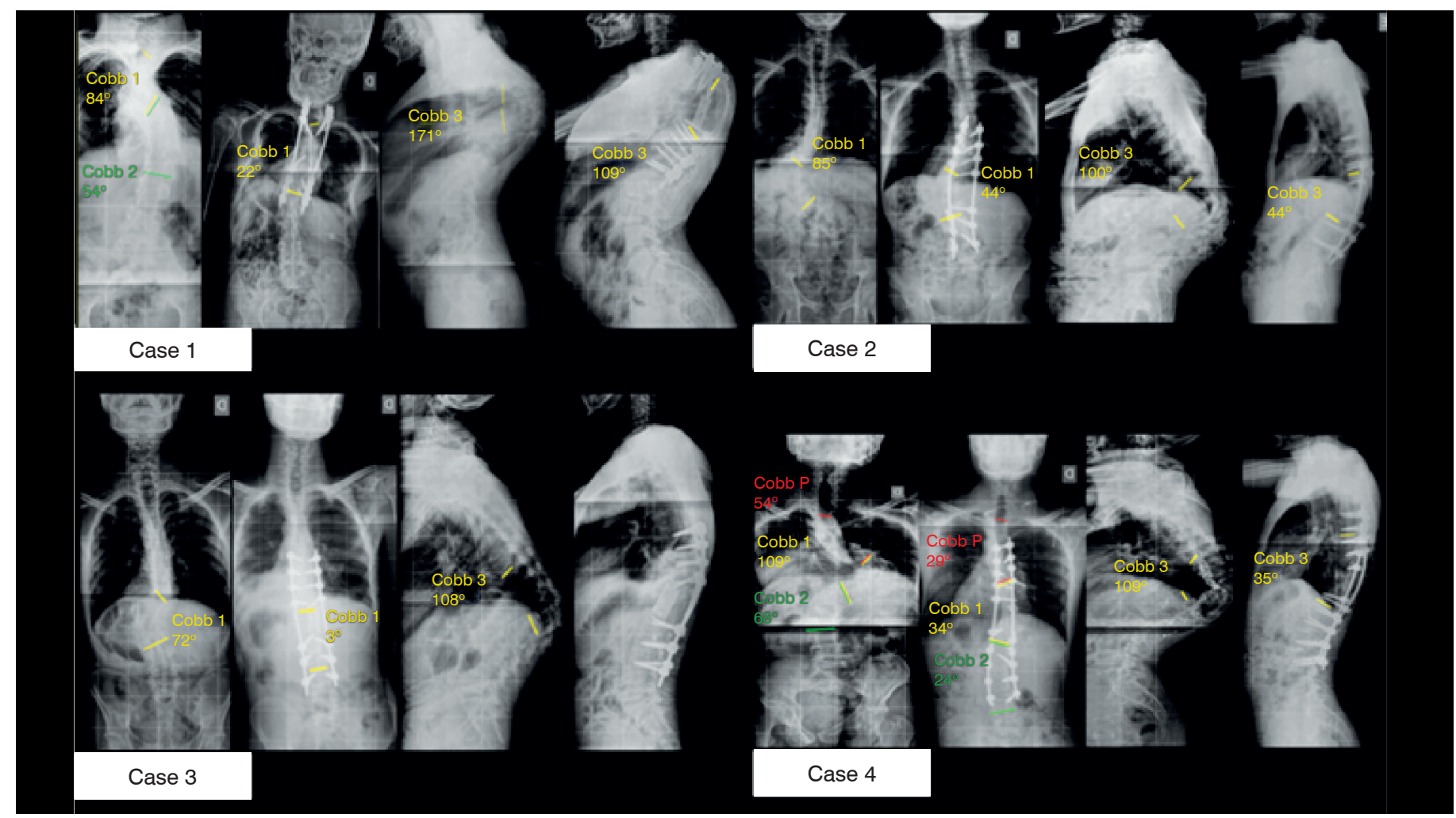

Figure 2. Postoperative radiographical results of the correction of the deformities of the four study patients. 


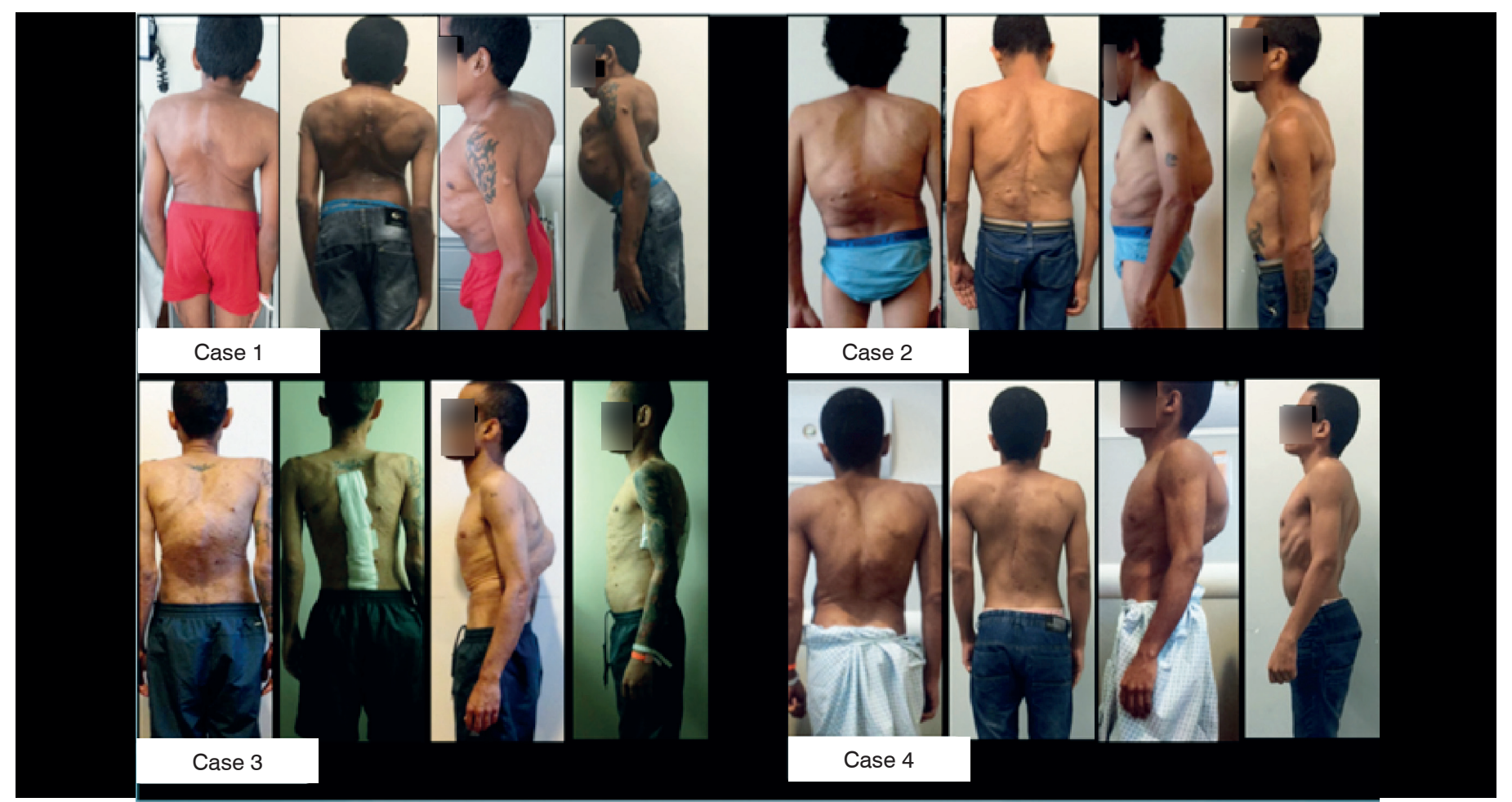

Figure 4. Preoperative and comparative postoperative images of the final outcome following correction of the deformity of the four study patients.

Table 1. Clinical and radiological results of the correction of severe kyphoscoliosis of NF-1 by multiple-level PVCR.

\begin{tabular}{|c|c|c|c|c|c|c|}
\hline & Case 1 & Case 2 & Case 3 & Case 4 & Average & $\%$ correction \\
\hline Age & $23 y$ & $28 y$ & $32 y$ & $24 y$ & $26 y$ 6m & ----- \\
\hline Sex & M & M & M & M & ---- & ---- \\
\hline Follow Up & $24 m$ & $30 \mathrm{~m}$ & $20 \mathrm{~m}$ & $22 m$ & $27 m$ & ----- \\
\hline Levels VCR & 5 & 2 & 2 & 3 & 3 & ---- \\
\hline $\begin{array}{c}\text { ASIA } \\
\text { (Preoperative) }\end{array}$ & E & E & $\mathrm{E}$ & $\mathrm{E}$ & ----- & ----- \\
\hline $\begin{array}{l}\text { ASIA } \\
(6 \mathrm{~m})\end{array}$ & D & E & E & E & ----- & ----- \\
\hline Fusion & + & + & + & + & ---- & ---- \\
\hline $\begin{array}{c}\text { COBB Sag. } \\
\text { (Preoperative) }\end{array}$ & $171^{\circ}$ & $100^{\circ}$ & $108^{\circ}$ & $109^{\circ}$ & $122^{\circ}$ & ---- \\
\hline COBB Sag. $(6 \mathrm{~m})$ & $109^{\circ}$ & $44^{\circ}$ & $36^{\circ}$ & $35^{\circ}$ & $56^{\circ}$ & $54.09 \%$ \\
\hline $\begin{array}{c}\text { COBB Cor. } \\
\text { (Preoperative) }\end{array}$ & $84^{\circ}$ & $85^{\circ}$ & $72^{\circ}$ & $109^{\circ}$ & $88^{\circ}$ & ---- \\
\hline COBB Cor. $(6 \mathrm{~m})$ & $22^{\circ}$ & $44^{\circ}$ & $3^{\circ}$ & $34^{\circ}$ & $26^{\circ}$ & $70,45 \%$ \\
\hline
\end{tabular}

Correction of severe, rigid deformities through three-column osteotomy, while effective, is technically highly complex, demanding specialized training and adequate hospital structure, and even so, it is not without risk, there being frequent complications. PVCRtype osteotomies performed at multiple levels are classified as grade 6, according to the classification of Frank Schwab et al., and should be used as the last resort in the correction of severe rigid deformities. ${ }^{16}$ In their study of 147 patients with spinal deformity, submitted to surgical treatment with PVCR, Lenke et al. reported a complication rate of $59 \% .{ }^{17}$ In our study, two of the four patients with middle term follow-up presented intraoperative motor-evoked potential alterations, and of these, one patient remained with an ASIA D neurological examination in the lower limbs after 6 months. In addition, one of the cases required two separate surgical approaches due to the severity of the curve and the amount of bleeding.

Traditionally, the recommended treatment in cases of severe kyphoscoliosis secondary to NF-1 is a combined approach by flexibilization and anterior vertebral arthrodesis associated with mechanical support through the fibula or metallic cage, followed by posterior arthrodesis, minimizing the risk of postoperative erosion due to dystrophic alterations and pseudoarthrosis, providing stability for a long period of time, though with varying outcomes in the final correction. ${ }^{18}$ Our study reported a consolidation rate of $100 \%$, confirmed by clinical and radiological evaluation, maintenance of the correction obtained, and quite satisfactory clinical results, but we know that these patients should be monitored for the rest of their lives because of the risk of continuous vertebral excavation and poor bone quality inherent to the disease.

There are studies that report good outcomes with the PVCR technique for the treatment of severe vertebral deformities in idiopathic, congenital, and neuromuscular deformities, ${ }^{13}$ but the literature addressing deformities secondary to NF-1 corrected using the PVCR technique are very scarce. ${ }^{6,19}$ In our study, we observed good results in relation to the rate of correction, consolidation, and associated complications.

The low number of patients is study limitation, but given the scarcity of the literature in relation to the topic, we consider the results obtained to be satisfactory and it is important that this information foster more investigations about the options for treatment of severe vertebral deformities using the PVCR technique.

\section{CONCLUSION}

The correction of severe kyphoscoliosis in patients with NF-1 is technically demanding and not free from complications, but given the limited correction technique possibilities, multiple-level PVCR has been shown to be a safe and effective technique.

All authors declare no potential conflict of interest related to this article. 
CONTRIBUTION OF THE AUTHORS: Each author made significant individual contributions to this manuscript. JAP (0000-0003-0643-7011)*, ALLB (0000-0002-65174285)*, and AGCB (0000-0002-8337-7676)* were the main contributors to the writing of the manuscript. JAP, ALLB, and AGCB performed the surgeries, followed-up with the patients, and collected the clinical data. JAP, AGCB, LECTS (0000-0003-2631-5492)*, and GBLA (0000-0003-4832$3813)^{\star}$ evaluated the statistical analysis data. JAP, LECTS, ALLB, GBLA, AGCB and RJMT (0000-0001-9455-1062)* conducted the bibliographical research and contributed to the intellectual concept of the study. ${ }^{*} \mathrm{ORCID}$ (Open Researcher and Contributor ID).

\section{REFERENCES}

1. Akbarnia BA, Gabriel KR, Beckman E, Chalk D. Prevalence of scoliosis in neurofibromatosis. Spine (Phila Pa 1976). 1992;17(Suppl):S244-8.

2. Yalcin N, Bar-on E, Yazici M. Impigimente of Spinal Cord by Dislocated Rib in Dystrophic Scoliosis Secondary to Neurofibromatosis Type 1. Spine (Phila Pa 1976). 2008;33(23):E881-6

3. Kaufman DL, Heinrich BS, Willett C, Perry A, Finseth F, Sobel RA, et al. Somatic instability of the NF2 gene in Schwannomatosis. Arch Neurol. 2003;60(9):1317-20.

4. Durrani AA, Crawford AH, Chouhdry SN, Saifuddin A, Morley TR. Modulation of spinal deformities in patients with neurofi bromatosis type 1. Spine (Phila Pa 1976). 2000;25(1):69-75

5. Winter RB, Lovell WW, Moe JH. J Bone Joint Surg 1975 [Am] 57:972-977.

6. Stoke GE, Lenke LG., Dorward IG. Posterior Vertebral Column Resection for the Treatment of Dystrophic Kyphosis Associated With Type-1 Neurofibromatosis. A Case Report and Review of the Literature. Spine (Phila Pa 1976). 2012;37(26):E1659-64.

7. Lenke LG, Sides BA, Koester LA, Hensley M, Blenke KM. Vertebral column resection for the treatment of severe spinal deformity. Clin Orthop Relat Res. 2010;468(3):687-99.

8. Suk SI, Chung ER, Kim JH, Kim SS, Lee JS, Choi WK. Posterior vertebral column resection for severe rigid scoliosis. Spine (Phila Pa 1976). 2005;30(14):1682-7.

9. Bradford DS, Tribus CB. Vertebral column resection for the treatment of rigid coronal decompensation. Spine (Phila Pa 1976). 1997;22(14):1590-9.

10. National Institutes of Health Consensus Development Conference Statement (1988) Neurofibromatosis. Bethesda, Md., USA, July 13-15, 1987. Neurofibromatosis 1.

11. Ponte A. Posterior column shortening for Scheuermann's kyphosis: an innovative one-stage technique. In: Haher T, Merola AA, eds. Surgical Techniques for the Spine. New York, NY:
Thieme Medical; 2003. p.107-13.

12. Tsirikos Al, Saifuddin A, Noordeen MH. Spinal deformity in neurofibromatosis type-1: diagnosis and treatment. Eur Spine J. 2005;14(5):427-39.

13. Lenke LG, Sponseller PD, Newton PO, Sucato DJ, Shah SA, Sides BA, et al. Complications After 147 Consecutive Vertebral Column resections for Severe Pediatric Spinal Deformity. Spine (Phila Pa 1976). 2013;38(2):119-32.

14. Parisini P, Di Silvestre M, Greggi T, Paderni S, Cervellati S, Savini R. Surgical correction of dystrophic spinal curves in neurofibromatosis. A review of 56 patients. Spine (Phila $\mathrm{Pa}$ 1976). 1999;24(21):2247-53.

15. Sirois JL III, Drennan JC. Dystrophic spinal deformity in neurofibromatosis. J Pediatr Orthop. 1990;10(4):522-6.

16. Schwab F, Blondel B, Chay E, Lenke LG, Tropiano P, Ames C, et al. The Comprehensive Anatomical Spinal Osteotomy Classification. Neurosurgery. 2014;74(1):112-20.

17. Crawford AH. Pitfalls of spinal deformities associated with neurofibromatosis in children. Clin Orthop Relat Res. 1989;(245):29-42.

18. Ponte A. Posterior column shortening for Scheuermann's kyphosis: an innovative one-stage technique. In: Haher T, Merola AA, eds. Surgical Techniques for the Spine. New York, NY: Thieme Medical; 2003. p.107-13.

19. Iwai C, Taneichi H, Inami S, Namikawa T, Takeuchi D, Kato N, et al. Clinical Outcomes of Combined Anterior and Posterior Spinal Fusion for Dystrophic Thoracolumbar Spinal Deformities of Neurofibromatosis-1: Fate of Nonvascularized Anterior Fibular Strut Grafts. Spine (Phila Pa 1976). 2013;38(1):44-50. 